\title{
Changes in mechanical properties of concrete due to ASR
}

\author{
Cambios en las propiedades mecánicas del hormigón debido a la ASR \\ Hans W. Reinhardt ${ }^{\mathrm{a}, *}$, Hasan Özkan ${ }^{\mathrm{b}}$, Oliver Mielich ${ }^{\mathrm{c}}$ \\ a Prof. Dr.-Ing., Department of Construction Materials, University of Stuttgart, Stuttgart, Germany \\ b Dipl.-Ing., Materials Testing Institute, University of Stuttgart, Stuttgart, Germany \\ ${ }^{c}$ Dr.-Ing., Materials Testing Institute, University of Stuttgart, Stuttgart, Germany \\ Received 24 August 2017; accepted 9 February 2018 \\ Available online 25 April 2018
}

\begin{abstract}
Alkali-Silica Reaction (ASR) is one of the most severe damage reactions of concrete. There are at least two different mechanisms of ASR: The most common is the rapid disruption of siliceous aggregates at the surface of the grain, which occurs in flint and opal sandstone, for example: The others are called slow reacting aggregates, and refer, for example, to cracking of the grain of greywacke and quartz porphyry. Both reactions are due to the dissolving of $\mathrm{SiO}_{2}$ by alkalis. The present paper reports on tests on slow reacting aggregates.

While most studies in the literature concentrate on the expansion behavior of the aggregates, in this article focus is centered on the mechanical properties, such as strength and creep. The aggregates used are greywacke, quartz porphyry, and crushed sediments from the Upper Rhine Valley. (C) 2018 Published by Elsevier España, S.L.U. on behalf of Asociación Espaóola de Ingenieróa Estructural, ACHE.
\end{abstract}

Keywords: Concrete; Alkali-silica reaction (ASR); Expansion; Mechanical properties; Creep modulus

\section{Resumen}

La reacción álcali-sílice (ASR) es uno de los deterioros más importantes que se produce en el hormigón. Existen principalmente dos mecanismos de ASR: El más común es la irrupción rápida de los áridos silíceos en la superficie del grano que por ejemplo sucede con el pedernal y la arenisca opal, mientras que los otros mecanismos son los de áridos de reacción lenta y, por ejemplo se refieren al agrietamiento del grano de grauvaca y pórfido de cuarzo. Ambas reacciones se deben a la disolución del $\mathrm{SiO}_{2}$ por los álcalis. El presente trabajo versa sobre ensayos en áridos de reacción lenta.

Mientras que la mayoría de las investigaciones en la literatura se concentran en el comportamiento de expansión de los áridos, nosotros nos centramos en las propiedades mecánicas tales como resistencia mecánica y fluencia. Los áridos utilizados son grauvaca, pórfido de cuarzo y sedimentos triturados del Valle Alto del Rin.

(C) 2018 Publicado por Elsevier España, S.L.U. en nombre de Asociación Española de Ingeniería Estructural (ACHE).

Palabras clave: Hormigón; Reacción álcali-sílice (ASR); Expansión; Propiedades mecánicas; Módulo de fluencia

\section{Introduction}

ASR manifests itself mainly by expansion and cracking. The surface of concrete structures shows random cracking or, dependent of the loading direction longitudinal or transverse cracking.

\footnotetext{
* Corresponding author.

E-mail address: reinhardt@iwb.uni-stuttgart.de (H.W. Reinhardt).
}

It happens very frequently that such structures are abandoned although the loading capacity is still sufficient. This was the starting point of the investigation with several questions: What are the remaining compressive strength and tensile strength, what are the deformations due to expansion of the aggregates, due to shrinkage and creep when ASR happens. It may be more economic to analyze the state of a structure taking account of inherent mechanical properties and monitor the further behav- 
ior instead of demolishing the structure. That means that the mechanical properties have to be known.

In the current investigation, four types of aggregates have been used: a crushed greywacke from the Harz (GW), crushed gravel from the Upper Rhine Valley (OR), quartz porphyry from Halle (QP), and another quartz porphyry from the Black Forrest (QPSW). According to the $40^{\circ} \mathrm{C}$ fog-room test [1] the first three aggregates were alkali sensitive while the forth aggregate was insensitive. The first three aggregates belong to the category of slow reacting aggregates i.e. an ASR damage would occur in practice only after about 15 years. However there are many structures mainly in the East part of Germany, which suffer from such signs of deterioration.

\section{Concrete composition}

A CEM I 32.5 R according to EN 197-1 [2] was used with addition of $\mathrm{K}_{2} \mathrm{SO}_{4}$ to the mixing water such that the $\mathrm{Na}_{2} \mathrm{O}_{\text {equi. }}$ amounted to $1.30 \mathrm{M}-\%$. The concrete was made with $400 \mathrm{~kg} / \mathrm{m}^{3}$ cement and a water to cement ratio of $0.45 .30 \mathrm{M}-\%$ of the aggregates were inert quartz sand up to $4 \mathrm{~mm}, 70 \mathrm{M}-\%$ were the coarse aggregates up to $16 \mathrm{~mm}$ grain size. The grading curve followed almost a Fuller parabola.

\section{Testing program}

For strength testing, $150 \mathrm{~mm}$ cubes and cylinders with $150 \mathrm{~mm}$ diameter and $300 \mathrm{~mm}$ length were produced. Modulus of elasticity, creep and shrinkage were determined on cylinders, compressive strength on cubes, tensile strength on dog-bone specimens, deformation due to ASR in the $40^{\circ} \mathrm{C}$ fog room on cylinders. Testing took place before and directly after installation of the 28 days moist cured specimens in the fog room and after 140, 280 and 560 days storage in the fog room.

For creep testing, cylinders were mounted in the test rig. The compressive force was applied by a hydraulic ram and held constant by Belleville springs. The deformation was measured with dial gauges. The stress was decided to be one third of the characteristic strength of concrete after 28 days standard curing. The specimens were taken out of the fog room after the predetermined time, transported to the creep room with constant climate of $23{ }^{\circ} \mathrm{C}$ and $80 \% \mathrm{RH}$, mounted in the test rig, and loaded. $80 \%$ $\mathrm{RH}$ was used because ASR had to continue, from experience it is known that ASR would stop at lower relative humidity [3].

\section{Testing results}

\subsection{Expansion in the fog room}

Concrete which is affected by ASR typically exhibits expansion in moist environment. The specimens were stored at $40^{\circ} \mathrm{C}$ and almost $100 \%$ RH for a certain time. The length change is plotted in Fig. 1. The dots give the experimental results, the lines are generated with the approximation function of Larive [4].

Obviously, the crushed gravel from the Upper Rhine Valley expanded most, the greywacke is second, quartz porphyry from Halle is three, and quartz porphyry from the Black Forest

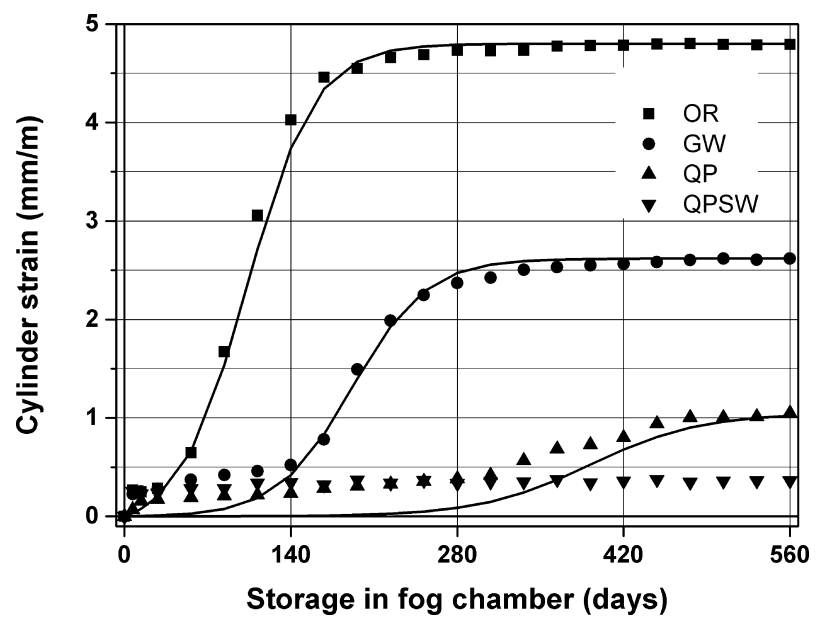

Figure 1. Expansion of specimens in the fog room, function of Larive [4]: $\varepsilon(t)=$

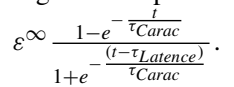

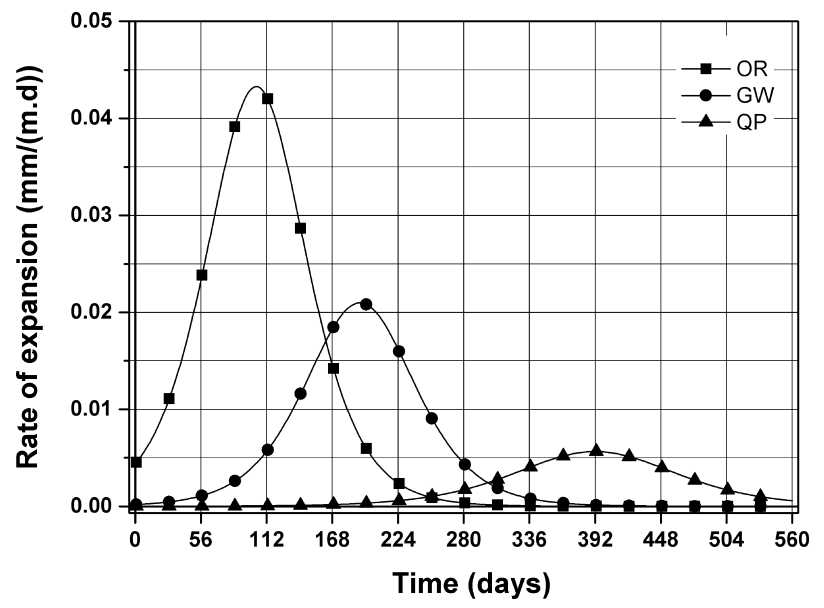

Figure 2. Rate of expansion.

does not expand. The expansion follows always an S-curve as known from Larive [4]. All lines start at a low level, increase then strongly and finally stay with an asymptotic maximum. The time of strong increase depends on the reactivity of the aggregate. The rate of expansion is plotted in Fig. 2, it represents the first derivative of the Larive function.

Three aggregates were suitable for the determination of the expansion rate, crushed gravel from the Upper Rhine Valley (OR), greywacke (GW) and quartz porphyry (QP). OR exhibits the maximum at $130 \mathrm{~d}$ while $\mathrm{GW}$ shows the maximum at $190 \mathrm{~d}$. QP is less pronounced with a maximum at $392 \mathrm{~d}$. The typical shape of the curve is very important and can later be used for the prediction of expansion in real structures.

\subsection{Modulus of elasticity}

It has been discussed before [5] that the dynamic modulus of elasticity is not a reliable measure to characterize ASR. The static modulus, however, depends strongly on the degree of ASR [6]. Therefore, the modulus has been determined in static experiments according to [7]. Table 1 shows the results. 
Table 1

Static modulus of elasticity of concrete measured after a certain storage time in the fog room in $\mathrm{MPa}$ (in brackets: the relative value in \%), mean of three specimens.

\begin{tabular}{lllll}
\hline \multirow{2}{*}{ Type of aggregate After 28 d curing } & \multicolumn{4}{l}{ Storage time in $40{ }^{\circ} \mathrm{C}$ fog room in days } \\
\cline { 3 - 5 } & & 140 & 280 & 560 \\
\hline OR & $37,702(100)$ & $15,805(42)$ & $20,750(55)$ & $28,934(77)$ \\
GW & $40,302(100)$ & $43,391(108)$ & $16,440(41)$ & $25,931(64)$ \\
QP & $36,031(100)$ & $41,078(114)$ & $41,551(115)$ & $22,342(62)$ \\
QPSW & $31,729(100)$ & $38,682(122)$ & $39,543(125)$ & $40,191(127)$
\end{tabular}

Table 2

Compressive strength of concrete in MPa measured after a certain storage time in the fog room (in brackets: the relative value in \%), mean of three specimens.

\begin{tabular}{|c|c|c|c|c|}
\hline \multirow[t]{2}{*}{ Type of aggregate } & \multirow[t]{2}{*}{ After $28 \mathrm{~d}$ curing } & \multicolumn{3}{|c|}{ Storage time in $40^{\circ} \mathrm{C}$ fog room in days } \\
\hline & & 140 & 280 & 560 \\
\hline OR & $52.1(100)$ & $57.9(111)$ & $61.5(118)$ & $65.4(125)$ \\
\hline GW & $50.6(100)$ & $69.2(137)$ & $71.4(141)$ & $72.7(143)$ \\
\hline QP & $53.4(100)$ & $69.6(130)$ & $74.5(140)$ & $81.5(153)$ \\
\hline QPSW & $54.5(100)$ & $72.5(133)$ & $74.2(136)$ & $83.8(154)$ \\
\hline
\end{tabular}

The elastic modulus of crushed gravel of the Upper Rhine valley decreases strongly after $140 \mathrm{~d}$ and exhibits only $42 \%$ of the original value. Thereafter it increases again. The other aggregates show an opposite behavior. The modulus increases due to good hydration conditions $\left(40^{\circ} \mathrm{C}\right.$ and water saturation of the ambient air) firstly and decay only after 280 or 560 days. The insensitive quartz porphyry from the Black Forest increases continuously. Comparing with Fig. 2 shows that the minimum value of the elastic modulus coincides roughly with the maximum reaction rate.

\subsection{Compressive strength}

Compressive strength has been determined on $150 \mathrm{~mm}$ cubes. Table 2 shows the results as mean of three specimens.

All concretes start at about $50 \mathrm{MPa}$ and increase continuously to 65-84 MPa depending on the aggregate. The strength increase is also due to the favorable hydration conditions. Obviously, ASR did not affect the compressive strength which means that the compressive strength cannot be used as indicator of ASR.

\subsection{Tensile strength}

The investigation of the splitting tensile strength was very limited. The results of aggregate OR and QP are shown in Table 3.

The strength of OR decays after 140 days in the fog room to $1.15 \mathrm{MPa}$ which is only $25 \%$ of the original value, it recovers to $31 \%$ after 280 days and to $44 \%$ after 560 days. Fig. 1 with the expansion of concrete has shown a strong expansion at about 140 days which explains the reduction of the tensile strength. Slow/late aggregate grains exhibit fracture in the grain [8] and, since the grain is responsible for the load transfer one must conclude that ASR has caused the strength loss. With ongoing
Table 3

Tensile strength of concrete in MPa measured after a certain storage time in the fog room (in brackets: the relative value in \%), mean of two specimens.

\begin{tabular}{|c|c|c|c|c|}
\hline \multirow[t]{2}{*}{ Type of aggregate } & \multirow[t]{2}{*}{ After $28 \mathrm{~d}$ curing } & \multicolumn{3}{|c|}{ Storage time in $40^{\circ} \mathrm{C}$ fog room in days } \\
\hline & & 140 & 280 & 560 \\
\hline OR & $4.68(100)$ & $1.15(25)$ & $1.43(31)$ & $2.04(44)$ \\
\hline QP & $3.99(100)$ & $3.40(85)$ & - & $3.19(80)$ \\
\hline
\end{tabular}

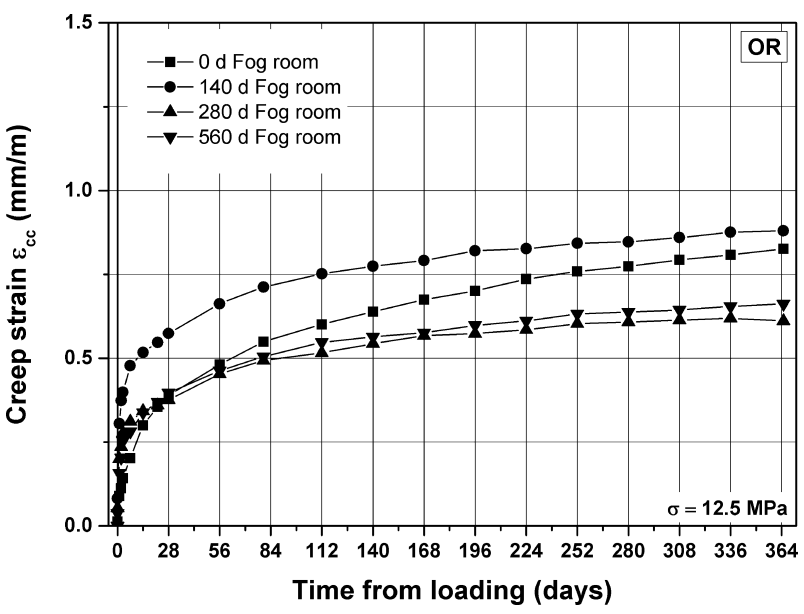

Figure 3. Creep strain of aggregate OR.

hydration strength recovers partly but cannot reach the original value again. QP shows respective values of $117 \%$ after 280 days and $80 \%$ after 560 days. A look to Fig. 1 reveals that ASR has started only after about 320 days which means that ongoing hydration has caused the strength increase at 280 days. Later strength decreases to $80 \%$ due to ASR. Comparing the development of compressive strength with tensile strength, the two properties do not follow the same manner. This has been reported also by other researchers [9]. Thus, the tensile strength is a better indicator for ASR than compressive strength.

\subsection{Creep under compressive load}

Figs. 3-6 show the development of strain with time as mean of two specimens. The stress is constant during the time under load, however it depends on the aggregate. As said before the stress level has been chosen as one third of the characteristic strength after 28 days standard curing. The diagrams give the information. The legend informs about the pre-storage in the $40^{\circ} \mathrm{C}$ fog room. Of course, this situation is artificial, however since the climate in the testing room is taken constant with $80 \% \mathrm{RH}$ one can assume that ASR is still progressing. (Remark: Although the creep strains are negative (shortening) they are plotted with a plus sign, i.e. as absolute values.)

Fig. 3 refers to the crushed gravel of the Upper Rhine Valley.

The specimens exhibit the typical behavior. Creep is progressing the most in the first 28 days thereafter creep rate diminishes. One must have in mind that the specimens underwent a specific pre-conditioning and that they are of different age. The two aspects may be opposing each other. The amount of creep is 


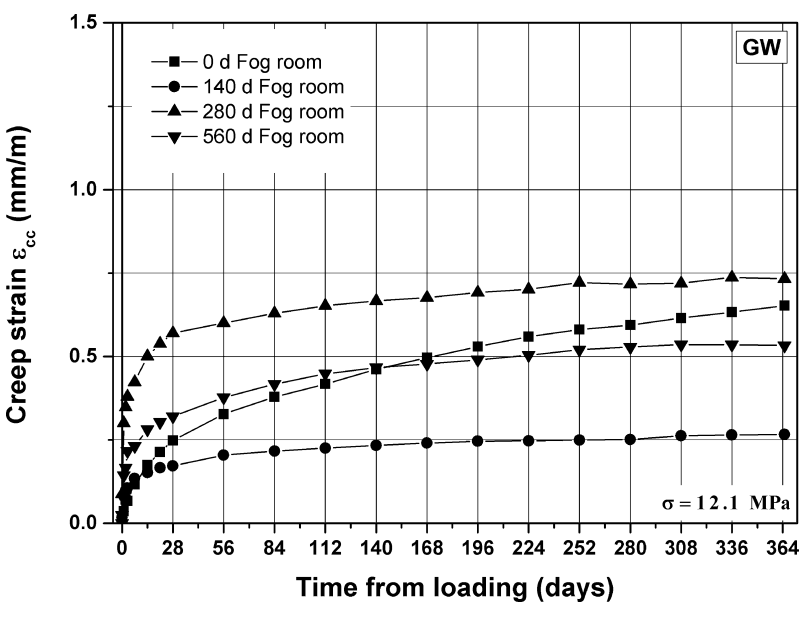

Figure 4. Creep strain of aggregate greywacke.

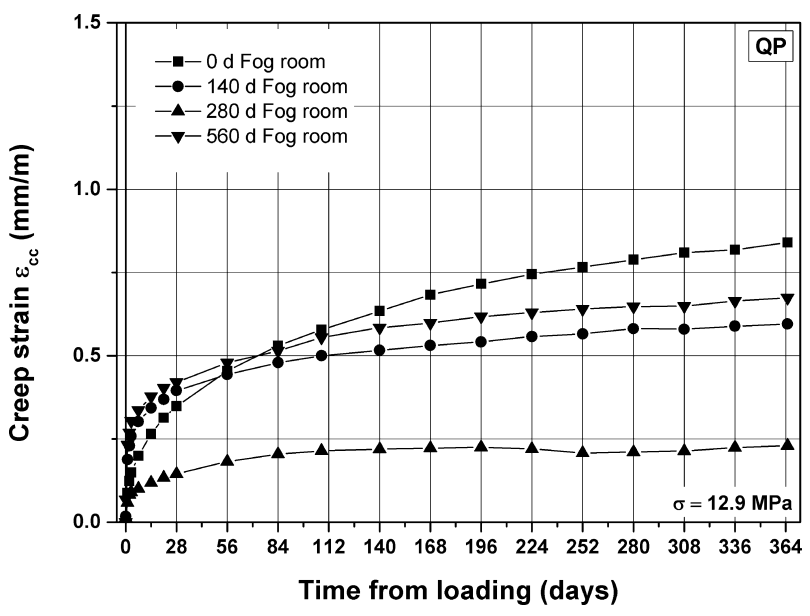

Figure 5. Creep strain of aggregate QP.

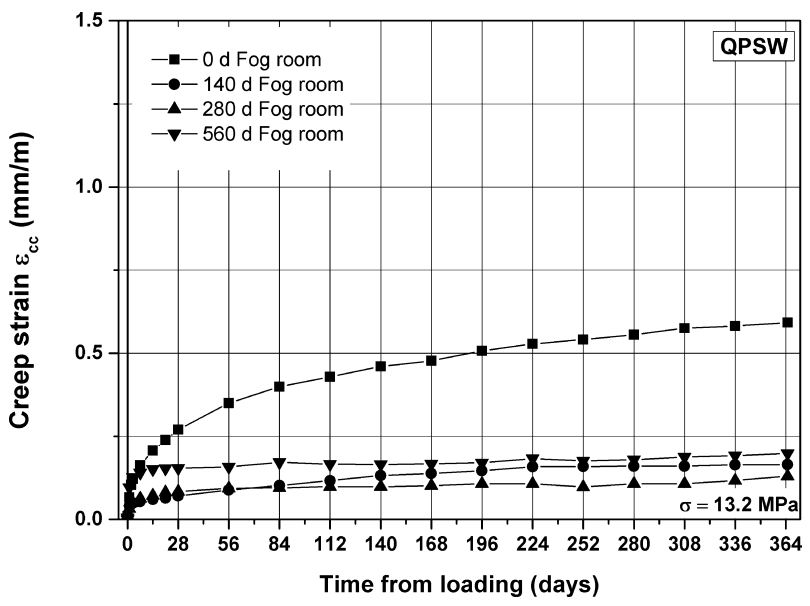

Figure 6. Creep strain of aggregate QPSW.

largest for the specimens which were stored in the fog room for 140 days. Looking to Fig. 2 one can see that this is the time of strongest reaction. The specimens with 280 and 560 days storage show less creep which is a token of greater hydration.

Fig. 4 belongs to the greywacke.
Table 4

Creep modulus of concrete in MPa measured after 365 days loading and after a certain pre-storage time in the fog room, mean of two specimens.

\begin{tabular}{lrrrr}
\hline Pre-storage & \multicolumn{4}{c}{ Type of aggregate } \\
\cline { 2 - 5 } & \multicolumn{1}{c}{ OR } & \multicolumn{1}{c}{ GW } & QP & QPSW \\
\hline 28 days moist curing & 10,520 & 12,518 & 10,967 & 13,214 \\
140 days in fog room & 6117 & 21,393 & 14,159 & 25,056 \\
280 days in fog room & 11,596 & 5956 & 23,195 & 28,021 \\
560 days in fog room & 11,030 & 10,531 & 9480 & 25,154 \\
\hline
\end{tabular}

The curves more spread than it was in the case of OR. The largest creep occurs for concrete which was stored in the fog room for 280 days. This time coincides roughly with the time of greatest ASR reaction. The lower curve for 140 days must be caused by more hydration compared to the curve without storage in the fog room. The 560 days curve must be attributed to the ongoing ASR.

Fig. 5 shows the results of the quartz porphyry from Halle.

The concrete which had no pre-treatment in the fog room shows the largest creep. Compared to the others it is the youngest concrete. The line for the $140 \mathrm{~d}$ concrete is lower and the line for the $280 \mathrm{~d}$ concrete is even lower. This behavior can be attributed to the ongoing hydration without effect of ASR. The line for the $560 \mathrm{~d}$ pre-treatment approaches almost the line of the zero concrete, i.e. ASR influences creep considerably.

Fig. 6 refers to the quartz porphyry from the Black Forrest, the aggregate which is insensitive to ASR.

This figure shows best the influence of progressing hydration. The zero pre-treatment concrete exhibits the largest creep and the other lines lie close together.

Comparing the four foregoing figures, one can see a common feature: The aggregates which are ASR sensitive show a larger creep than the insensitive aggregate QPSW. The aggregates OR and GW which undergo the largest expansion due to ASR show larger creep strain than the lass expanded QP. On the other and, the simultaneous influence of absolute age of concrete became obvious.

\section{Creep modulus}

If structures have to be analyzed with respect to long-term deformation one can have a look to polymer technology. To this end, their engineers use the so-called creep modulus. The creep modulus $E_{\mathrm{cr}}$ is the quotient of stress divided by the load induced strain $E_{\mathrm{cr}}=\sigma /\left(\varepsilon_{\mathrm{el}}+\varepsilon_{\mathrm{cr}}\right)$ with $\varepsilon_{\mathrm{el}}$ the elastic strain and $\varepsilon_{\text {cr }}$ the creep strain. The creep modulus could also be used for concrete structures. Table 4 shows the numbers calculated with the deformation at one year (without shrinkage, of course).

The creep modulus diminishes with loading time because creep increases, that is why the first row shows considerably smaller values than the ones in Table 1 which contains Young's modulus. The pre-storage in the $40^{\circ} \mathrm{C}$ fog room affects the creep modulus again. The aggregate OR shows the largest decrease after $140 \mathrm{~d}$, GW has the least value after 280 days, QP follows after 560 days fog-room storage. One depicts here the same tendency as has been discussed with creep. As expected, 
QPSW exhibits the largest values. It also reflects the feature of Figs. 1 and 2.

\section{Outlook}

The aim of the investigations was to increase the knowledge with respect to short-time and long-time mechanical properties of ASR affected concrete. The knowledge is suitable for the analysis of the state structures in the light of loading capacity and deformation. However, there are several disciplines questioned: firstly, the testing results have to be transposed to real life of the structure, secondly, ASR development has to be modeled for the structure in terms of time and space, and thirdly, an ASR affected structure should be monitored continuously. As the first point is concerned there are results of ASR at real exposure which show that the development of ASR takes about ten times more time than in the $40^{\circ} \mathrm{C}$ fog room [10]. The second point can be satisfied with the aid of modern finite-element codes which take account of physical aspects (diffusion, permeation, temperature, humidity) and stress [11]. The nowadays monitoring techniques are able to monitor continuously and wireless the crucial spots of structures [12]. In any case there is a strong demand for good knowledge of the material.

\section{Final conclusions}

The investigations have been performed on concrete with three types of slow reacting alkali sensitive aggregates and one insensitive aggregate. The following conclusions can be drawn.

The expansion due to ASR measured after a certain storage time in the $40^{\circ} \mathrm{C}$ fog room follows an S-curve for the three concretes with alkali sensitive aggregate. The time of maximum reaction rate is strongly dependent on the type of aggregate.

The static modulus of elasticity decreases with ASR to a minimum value and increases thereafter again. The time of minimum coincides roughly with the maximum reaction rate.

The compressive strength seems not to be affected by ASR.

The tensile strength decays with time in the fog room. Compressive and tensile strength do not follow the same behavior.

Creep is enlarged by ASR. The largest creep rate goes together with the largest progress of ASR.

As a mean for the analysis of long-term deformation the creep modulus has been calculated which shows a similar tendency as creep.

The outlook provides some ideas how the gained knowledge can be used in the analysis of structures in real environment.
All conclusions are only valid for the material tested. One has to be very cautious in drawing general conclusions because the aggregates are of natural origin and vary from place to place. It can happen that rocks taken from the same quarry differ strongly.

\section{Acknowledgement}

The first author has experienced a long lasting friendship with Carmen Andrade. We met at many events of RILEM, at committee meetings, symposia and workshops. Carmen showed always much interest in various fields which have triggered research of common interest. Thank you. Ad multos annos!

The German Research Community has greatly supported the project under RE 691/39-1 which is thankfully acknowledged.

\section{References}

[1] Deutscher Ausschuss für Stahlbeton (DAfStb), Vorbeugende Maßnahmen gegen schädigende Alkalireaktion im Beton (Alkali Richtlinie), Beuth Verlag, Berlin, Deutscher Ausschuss für Stahlbeton, Oktober, 2013.

[2] EN 197-1: 2011 Cement. Composition, specifications and conformity criteria for common cements.

[3] D. Stark, The moisture condition of field concrete exhibiting alkali silica reaction, in: Durability of Concrete, 2nd Int. Conf. Montreal Canada, Vol. II ACI, SP 126, Detroit, 1991, pp. 973-987.

[4] C. Larive, Apports combinés de 1 'expérimentation et de la modélisation à la compréhension de l'alcali-réaction et de ses effets mécaniques, thèse de doctorat, L'École Nationale de Ponts et Chaussées, 1997.

[5] H.W. Reinhardt, O. Mielich, Static vs. dynamic Young's modulus as indicator for ASR degradation, in: C. Leung, K.T. Wan (Eds.), Advances in Construction Materials through Science and Engineering, 2011, RILEM PRO 79, S. 104 (Abstract book) ISBN 978-2-35158-116-2.

[6] P. Helene, M. Carvalho, J. Pachero, Engineering field tests for alkaliaggregate reaction, Struct. Concr. J. Fib. 18 (2017) 349-355.

[7] DIN 1048-5: 1991 Testing methods for concrete; hardened concrete, specially prepared specimens.

[8] H.W. Reinhardt, O. Mielich, Fracture toughness of alkali-sensitive rocks in alkaline solution, Int. J. Rock Mech. Min. Sci. 70 (2014) 552-558

[9] "Alkali-aggregate reaction concrete" (ICAAR), proceedings volumes since 1974.

[10] E. Siebel, M. Böhm, I. Borchers, C. Müller, J. Bokern, E. Schäfer. AKRPrüfverfahren - Vergleichbarkeit und Praxis-Relevanz, Betontechnische Berichte 2004-2006, VDZ Düsseldorf.

[11] J. Ožbolt, MASA - MAcroscopic Space Analysis. Bericht zur Beschreibung des FE Programmes MASA, Institut für Werkstoffe im Bauwesen, Universität Stuttgart, Stuttgart, 1998.

[12] C. Maierhofer, H.-W. Reinhardt, G. Dobmann, Non-destructive Evaluation of Reinforced Concrete Structures, vols. 1 and 2, Woodhead Publ, Oxford, 2010 . 